\title{
PENGARUH CURRENT RATIO, QUICK RATIO, NET PROFIT MARGIN, DAN EARNINGS PER SHARE TERHADAP RETURN SAHAM PADA PT. MNC DI BURSA EFEK INDONESIA
}

\author{
Sandy Oka Fernando ${ }^{1)}$, Dr. Agus Sutardjo ${ }^{2)}$, Nova Begawati ${ }^{3)}$ \\ Jurusan Manajemen, Fakultas Ekonomi, Universitas Ekasakti Padang ${ }^{1)}$ 2) 3)
}

\begin{abstract}
Abstrack - Tujuan penelitian ini adalah untuk mengetahui pengaruh current rasio, quick rasio, met profit margin dan earning per share terhadap return saham pada PT. MNC MEDIA yang terdaftar di Bursa Efek Indonesia. Populasi sekaligus sampel dalam penelitian ini adalah data keuangan PT. MNC MEDIA selama 9 tahun dimulai tahun pencatatan perdana hingga tahun 2016. Data yang digunakan adalah data sekunder. Teknis analisis data adalah dengan menggunakan asumsi klasik dan regresi berganda diolah dengan aplikasi spss 23. Hasil penelitian menunjukkan (1) current rasio, quick rasio, net profit margin dan earning per share secara simultan berpengaruh tidak signifikan terhadap return saham pada PT. MNC MEDIA. (2) secara parsial hanya variabel earning per share yang berpengaruh signifikan terhadap return saham, sedangkan current rasio, quick rasio dan net profit margin berpengaruh tidak signifikan. Berdasarkan penelitian ini, penulis menyarankan agar perusahaan memperhatikan ke empat rasio ini untuk digunakan sebagai dasar perbaikan kinerja perusahaan, dengan banyaknya saham diminati akan membuat nilai jual saham perusahaan ikut naik, dan tentunya nilai perusahaan juga akan naik.
\end{abstract}

Kata kunci : Current Rasio, Quick Rasio, Net Profit Margin, Earning per Share, Harga Saham.

\section{PENDAHULUAN}

\section{Latar Belakang}

Perkembangan investasi yang semakin hari semakin pesat di indonesia. Hal ini ditandai dengan jumlah transaksi perusahaan yang go public, investor dan pelaku pasar modal lainnya yang terus meningkat. Bagi perusahaan pemilihan sumber dana merupakan sebuah hal yang penting, sebab hal ini akan mempengaruhi struktur modal perusahaan tersebut, yang pada akhirnya tentu akan berpengaruh juga terhadap kinerja perusahaan.

Harga saham di pasar modal merupakan ukuran yang objektif mengenai nilai investasi pada sebuah perusahaan. Oleh karena itu, harga-harga saham merupakan harapan investor. Keberagaman harga saham sangat dipengaruhi oleh kinerja perusahaan yang bersangkutan. Kinerja perusahaan akan menentukan tinggi rendahnya harga saham di pasar modal.

Harga saham yang tertera di pasar modal, dipengaruhi oleh permintaan dan penawaran pasar, harga yang penulis maksud adalah nilai sekarang atau present value dari aliran khas yang diharapkan akan diterima. Perubahan harga saham-saham di pasar modal dapat dipengaruhi oleh berbagai macam informasi yang berasal dari luar perusahaan, misalnya kondisi perekonomian situasi sosial dan politik dalam negeri dan kebijakan pemerintah, serta informasi internal yang berasal dari dalam perusahaan yang berhubungan dengan kinerja perusahaan dan prospek di masa mendatang.

Pasar modal adalah tempat dimana berbagai pihak khususnya perusahaan 
menjual saham atau dikenal dengan istilah stock dan obligasi dengan tujuan dari hasil penjualannya nantinya akan dipergunakan sebagai tambahan dana atau memperkuat modal perusahaan." Berinvestasi pada pasar modal tak kurang kita dihadapkan pada dua hal yang perlu diperhatikan, hal pertama yaitu keuntungan yang kita inginkan atau expected return dan resiko atau risk yang mungkin bisa terjadi. Ini berarti berinvestasi dalam pasar modal menjanjikan keuntungan sekaligus resiko. Kepemilikan saham yang baik terlihat dengan berjalannya waktu dengan membandingkan pendapatan perusahaan. Investor saham mempunyai kepentingan terhadap informasi antara lain berupa laporan keuangan sebagai acuan untuk menentukan harga saham.

Dalam memilih saham, investor diharuskan mencari saham yang likuid, karena membeli saham yang tidak bisa dijual kembali di pasar modal tentu tidak ada gunanya, meskipun lonjakan-lonjakan harga saham justru banyak terjadi pada saham-saham perusahaan dengan kapitalisasi kecil. Memang jika kita memperhatikan harga saham di lantai bursa sangatlah menarik, ada saham yang naik atau turun dikarenakan mengikuti indexs harga saham gabungan, ada juga yang justru naik atau turun tidak sejalan dengan indexs saham gabungan.

Tinggi rendahnya harga saham sebuah emiten dipengaruhi oleh berbagai faktor seperti kinerja perusahaan, resiko, dividen, tingkat suku bunga, penawaran, permintaan, laju inflasi keadaan ekonomi secara nasional maupun global, serta kebijakan pemerintahan. Oleh karena faktor-faktor inilah membuat harga saham naik atau turun. Harga saham juga merupakan cerminan nilai perusahaan dimata masyarakat. Ketika harga saham tinggi, maka nilai perusahaan di mata masyarakat juga tinggi, begitu pula jika harga saham rendah, maka nilai perusahaan dimata masyarakat juga akan tidak baik.

Pada dasarnya investor mengukur kinerja suatu perusahaan berdasarkan kemampuan perusahaan tersebut mengelola sumber dana yang mereka punya untuk membayar kewajiban jatuh tempo mereka untuk menghasilkan profit. Kemampuan mereka dalam memperoleh laba dalam kegiatan operasional merupakan fokus utama dalam penilaian kinerja perusahaan, karena keuntungan merupakan indikator kemampuan perusahaan dalam memenuhi kewajibannya kepada para investor. Jika suatu perusahaan memiliki kinerja keuangan yang baik, maka bisa dipastikan para investor yang menanamkan modalnya diperusahaan terkait akan memperoleh keuntungan investasi. Penilaian kemampuan perusahaan dalam memperoleh laba dari investasi yang akan dilakukan disebut rasio profitabilitas.

Analisis laporan keuangan meliputi perhitungan dan interpretasi ratio dibutuhkan untuk bisa memahami informasi tentang laporan keuangan. Ratio yang dimaksud adalah perbandingan antara satu unsur dengan unsur lainnya yang terdapat dalam laporan keuangan. Ratio keuangan dapat dijadikan sebagai acuan dalam mengambil keputusan, serta bisa juga sebagai perbandingan kinerja perusahaan dengan yang lainnya. Dari eksternal, laporan keuangan dapat dipergunakan sebagai dasar untuk menentukan pembelian atau penjualan saham suatu perusahaan, pemberian pinjaman serta untuk memprediksi kekuatan keuangan perusahaan dimasa mendatang.

Analisis rasio keuangan bisa membantu pebisnis, pemerintah dan para pemakai laporan keuangan lainnya untuk menilai kondisi keuangan perusahaan. Pemakaian rasio keuangan dalam menggambarkan kinerja keuangan berdasarkan pada hasil penelitian terdahulu 
membuktikan bahwa terdapat pengaruh dan hubungan yang kuat antara rasio keuangan dengan perubahan Tingkat return saham yang dijanjikan perusahaan. Dan kegunaan rasio keuangan dalam mengukur dan memprediksi kinerja keuangan suatu perusahaan.

Dalam melakukan investasi di pasar modal apakah investor akan mempertimbangkan faktor fundamental beberapa perusahaan, contohnya kinerja perusahaan yang di gambarkan lewat rasio keuangan, tujuannya adalah untuk memperkirakan tingkat kemampuan perusahaan dalam membayar kewajiban jangka pendeknya serta kemampuan perusahaan dalam memperoleh keuntungan atau untuk memperkirakan harga yang akan diterima dimasa mendatang. Rasio keuangan yang digunakan adalah rasio likuiditas yaitu Current Rasio dan Quick Rasio serta rasio profitabilitas yaitu NetProfit Margin (NPM) dan Earning Per Share (EPS).

Dalam perkembangan kegiatan industri media pertelevisian memerlukan pembiayaan yang besar sehingga diperlukan pilihan sumber pembiayaan. Melalui sebuah pasar modal, industri tersebut dapat melakukan penawaran sahamnya kepada public, sehingga bagi perusahaan media televisi pertimbangan komposisi struktur modal perlu dilakukan. Karna struktur modal berperan dalam meningkatkan kinerja perusahaan.

Perusahaan media pertelevisian adalah salah satu sektor dari perusahaan jasa yang ada, dimana perusahaan tersebut bergerak dibidang jasa. Di Indonesia perusahaan media dapat berkembang seiring dengan perkembangan zaman, hal ini terlihat dari jumlah perusahaan yang terdaftar di Bursa Efek Indonesia dari waktu ke waktu yang semakin banyak, walaupun ada beberapa perusahaan media pertelevisian yang mengalami penurunan dikarnakan krisis ataupun tidak membaca permintaan pasar dengan baik. Di Indonesia perusahaan media berjumlah 15 stasiun televisi. Perusahaan media televisi terbesar di Indonesia adalah MNC MEDIA. MNC MEDIA merupakan media group televisi swasta terbesar yang berpusat di MNC TOWER Jakarta. MNC MEDIA merupakan induk dari 4 stasiun televisi besar nasional, empat stasiun televisi tersebut adalah RCTI, MNCTV, GTV, dan INEWS TV. Dengan pembagian fokus pemirsa yang berbeda beda.

Alasan dari dipilihnya MNC MEDIA dikarenakan, MNC MEDIA adalah media terbesar di Indonesia dan memiliki pangsa pasar serta jaringan yang paling luas di antara media-media televisi nasional swasta lainnya. MNC MEDIA adalah media yang mampu mempresentasikan keadaan industri media di Indonesia, tidak jarang media ini dijadikan dasar pembuatan program program siaran oleh para media pesaing. Kinerja perusahaan yang baik pada umumnya menjadi faktor utama bagi naiknya harga saham di pasar modal. Kinerja perusahaan terlihat dari laporan keuangan perusahaannya. Sehingga investor sangat memperhatikan kinerja keuangan perusahaan. Sebelum memutuskan membeli atau menjual saham, investor akan lebih dulu meneliti laporan keuangan perusahaan tersebut, banyak informasi penting yang terkandung dalam laporan keuangan tersebut, seperti laba bersih, laba bersih per lembar atau dikenal dengan earning per share (EPS).

\section{Perumusan Masalah}

Berdasarkan pada latar belakang
masalah yang telah dikemukakan,
perumusan masalah yang akan dibahas
dalam penelitian ini adalah:
1. Bagaimanakah
Current Rasio berpengaruh terhadap 
ReturnSahampada PT. MNC MEDIA di Bursa Efek Indonesia?

2. Bagaimanakah Quick Rasio berpengaruh terhadap Return Saham pada PT. MNC MEDIA di Bursa Efek Indonesia?

3. Bagaimanakah Net Profit Margin, berpengaruh terhadap Return saham pada PT. MNC MEDIA di Bursa Efek Indonesia?

4. Bagaimana Earning per Share berpengaruh terhadap Return Saham pada PT. MNC MEDIA di Bursa Efek Indonesia?

5. Bagaimana Current rasio, Quick rasio, Earning per Share dan Profit margin berpengaruh terhadap Return Saham pada PT. MNC MEDIA di Bursa efek Indonesia?

\section{LANDASAN TEORI}

\section{Current Rasio}

Menurut Irham Fahmi (2011:121) “ current rasio adalah ukuran yang umum digunakan oleh perusahaan dalam memenuhi kewaqjiban jangka pendeknya".

Menurut Kasmir (2011:134) “current rasio adalah rasio yang digunakan oleh perusahaan yang menggambarkan kemampuan perusahaan dalam membayar kewajiban jangka pendeknya secara keseluruhan". Menurut Brighton dan Houston (2010:138) " menjelaskan bahwa current rasio adalah suatu rasio yang menggambarkan kemampuan perusahaan membayar kewajiban jangka pendeknya dengan seluruh aktiva yang dimilikinya". Menurut Jumingan (2011:123) “ rasio lancar atau current rasio adalah rasio keuangan yang digunakan oleh perusahaan dalam menganalisis laporan keuangan mereka. Rasio lancar menggambarkan keadaan kasar dari tingkat likuiditas suatu perusahaan “. Menurut Harahap (2010:310) " rasio ini menjelaskan tentang bagaimana aktiva lancar menutupi kewajiban jatuh temponya “.

\section{Quick Rasio}

Menurut Jumingan (2011:125) “ Quick rasio adalah sebuah rasio keuangan yang mampu menggambarkan kemampuan perusahaan dalam membayar kewajiban jangka pendeknya tanpa memperhitungkan persediaan".

Menurut Kasmir (2012:140) “ quick rasio adalah rasio yang mampu memberikan gambaran tentang kemampuan perusahaan dalam membayar kewajiban jangka pendeknya, tanpa memperhitungkan nilai persediaan pada aset lancar". Menurut Brighton dan Houston (2010:141) " Quick Rasio adalah rasio keuangan yang digunakan oleh perusahaan, dimana rasio ini digunakan untuk mengukur kemampuan perusahaan dalam membayar kewajiban jangka pendeknya tanpa menghiraukan persediaan ".

\section{Return On Equity}

Menurut Kasmir (2012:196) "Return On Equitymerupakan rasio untuk menilai kemampuan perusahaan dalam mencari keuntungan dilihat dari ekuitas perusahaan. Rasio ini juga mengukur tingkat efektifitas manajemen suatu perusahaan.

\section{NetProfit Margin}

Margin laba bersih atau net profit margin adalah sebuah rasio keuangan yang digunakan oleh perusahaan untuk mengukur tingkat pendapatan bersih perusahaan yang bersumber dari penjualan selama satu tahun periode laporan keuangan..

Menurut Riyanto (2013:336) "Net Profit Margin adalah sebuah rasio keuangan yang digunakan untuk mengukur keuntungan netto per rupiah penjualan." Menurut Kasmir (2012:202) "net profit margin atau margin laba bersih merupakan rasio keuangan yang bertujuan untuk mengukur keuntungan dengan membandingkan antara laba setelah bunga dan pajak dengan penjualan. Menurut Harahap (2010:305) “ net profit margin adalag sebuah rasio keuangan yang digunakan untuk menunjukkan seberapa 
besar persentase pendapatan bersih yang diperoleh oleh perusahaan dari setiap penjualan".

\section{Earning per Share}

Hal yang harus diperhatikan dalam berinvestasi adalah tingkat laba per lembar saham yang akan dierima investor atau dikenal dengan earning per share, informasi EPS perusahaan menunjukkan besarnya laba bersih perusahaan yang siap dibagikan kepada para pemegang saham.

Menurut Kasmir (2012:207) “ laba per lembar saham atau rasio nilai buku merupakan rasio untuk mengukur keberhasilan manajemen dalam mencapai keuntungan bagi pemegang saham. Rasio yang rendah berarti manajemen belum bisa memuaskan pemegang saham, sebaliknya jika rasio yang tinggi, menjadikan cerminan kesejahteraan pemegang saham meningkat". Dengan artian jika EPS nya tinggi, maka tingkat return saham yang ditawarkan perusahaan juga akan tinggi. Menurut Jumingan (2010) EPS adalah rasio yang digunakan oleh perusahaan untuk mengukur laba per lembar saham, caranya dengan membagi modal sendiri dengan saham biasa yang beredar".

Menurut Irham Fahmi (2012:138) “ Earning per share adalah sebuah rasio keuangan yang menjadi gambaran tentang pendapatan per lembar saham dalam bentuk pemberian keuntungan terhadap para pemegang saham perusahaan dari setiap lembar saham tersebut".

\section{Return Saham}

Menurut Tandelilin (2010:7)" alasan utama orang berinvestasi adalah untuk memperoleh keuntungan. Dalam konteks keuangan investasi. Keuntungan disebut 'return'. Tujuan dari berinvestasi menurut Tandelilin (2010:8) :

1. Mendapatkan kesejahteraan dimasa mendatang, orang berfikir bagaimana meningkatkan taraf hidupnya dimasa mendatang.

2. Membantu mengurangi tekanan inflasi

3. Terciptanya keuntungan dari investasi yang berkesinambungan.

\section{Penghematan pajak}

Menurut Jogiyanto hartono (2011:109) return merupakan hasil yang diperoleh dari investasi". Artinya segala hal yang kita terima yang berasal dari kegiatan berinvestasi itulah yang dinamakan return.Menurut Robert ang (2010:23) "return saham adalah tingkat keuntungan yang dinikmati oleh pemodal atas suatu investasi".Dalam melakukan investasi, investor selalu berorientasi terhadap Return Saham, artinya segala kegiatan atau tindakan investor dalam berinvestasi pastilah dilakukan demi memperoleh return.Return saham sendiri terbagi atas dua yaitu realize return dan expected return. Realize return adalah return yang sebenarnya di bayarkan oleh perusahaan terhadap para pemegang saham, artinya realize return adalah jumlah yang sebenarnya investor terima dari hasil kegiatan investor dalam berinvestasi. sedangkanexpected return adalah return yang diharapkan oleh investor. Dalam melakukan investasi saham, biasanya para investor akam dihadapkan pada 2 return berupa capital gain atau capital lost. Capital gain adalah selisih harga jual saham investor saat menjual saham dengan harga saat beli bernilai positif.Artinya saat investor membeli saham, nilainya lebih rendah dari pada saat investor menjual saham tersebut. Sedangkan apabila harga saham saat investor membeli saham lebih tinggi dari harga jualnya maka capital lost yang diterima investor.

Hubungan Current Rasio, Quick Rasio, Net Profit Margin Dan Earning Per Share Dengan Return Saham

Sebelum berinvestasi r
individual atau organisasi
memastikan bahwa investasi
lakukan adalah tepat. Hal ini dapat
dilakukan dengan menerapkan berbagai
alternative cara penilaian, apakah saham
yang dibeli atau dipilih benar benar
merupakan saham yang bakal
mendatangkan keuntungan di waktu yang
akan datang. Keuntungan yang diharapkan


tentu saja return saham yang menghasilkan capital gain.

Secara garis besar para investor tentu akan mempertimbangkan segala aspek, sebelum mereka melakukan investasi, terutama sekali laporan keuangan berupa analisis investor terhadap keadaan internal perusahaan tersebut, karna meski tujuan dari berinvestasi adalah laba, faktor likuid atau tidaknya sebuah perusahaan perlu juga diperhatikan.

$\begin{array}{ccc}\text { Menurut Harahap } & (2010: 301) \text { “ } \\ \text { Rasiolikuiditas adalah rasio yang }\end{array}$ menggambarkan kemampuan perusahaan. Untuk menyelesaikan kewajiban berupa kewajiban jangka pendeknya, rasio ini dapat dihitung melalui laporan keuangan pada pos aktiva lancar dan aset lancarnya ".

Menurut Kasmir (2012:196) "Rasio profitabilitas merupakan rasio untuk menilai kemampuan perusahaan dalam mencari keuntungan. Rasio ini juga mengukur tingkat efektifitas manajemen suatu perusahaan.Hal ini ditunjukan oleh laba yang dihasilkan dari penjualan dan pendapatan investasi.Dari beberapa alternatif penilaian investasi, salah satunya adalah analisis secara fundamental. Artinya seorang calon investor mencoba meramal masa depan portofolio yang dipilihnya, berdasarkan performa perusahaan yang digambarkan dari data sekunder perusahaan, berupa neraca, laporan laba rugi, perubahan modal, arus modal serta laporan pendukung lainnya yang wajib diketahui oleh seorang calon investor. Rasio profitabilitas yang menunjukan kemampuan perusahaan dalam menghasilkan keuntungan merupakan salah satu cara untuk mengetahui performa perusahaan. Jika kategori perusahaan menjanjikan untuk berinvestasi maka investor akan berbondong-bondong membeli saham tersebut.

Hal ini tentu disebabkan karna investor tergiur dengan pengembalian investasi yang tinggi dari saham tersebut.Seperti yang dinyatakan Agus sartono (2012:109) bahwa :"..pemegang saham melihat dari segi profitabilitas dan risiko, karna kestabilan harga saham tergantung tingkat keuntungan ( return ) yang diperoleh dimasa mendatang".

\section{Hipotesis Penelitian}

Berdasarkan landasan teori dan penelitian terdahulu, maka hipotesis dalam penelitian ini adalah:

a. $\mathrm{H}_{1}=$ Diduga current rasio Berpengaruh Signifikan Terhadap Return Saham Pada PT. MNC MEDIA Di Bursa Efek Indonesia.

b. $\mathrm{H}_{2}=$ Diduga quick rasio berpengaruh Signifikan terhadapreturn saham pada PT. MNC MEDIA di Bursa Efek Indonesia.

c. $\mathrm{H}_{3}=$ DidugaNet Profit Margin berpengaruh Signifikan terhadap return saham pada PT. MNC MEDIA di Bursa Efek Indonesia.

d. $\mathrm{H}_{4}=$ DidugaEarning Per Share berpengaruh Signifikan terhadap return saham pada PT. MNC MEDIA di Bursa Efek Indonesia.

e. $\mathrm{H}_{5}=$ Diduga current rasio, quick rasio, net profit margin dan earning per share berpengaruh Signifikan terhadap return saham pada PT. MNC MEDIA di Bursa Efek Indonesia.

\section{METODE PENELITIAN}

\section{Metode pengumpulan data}

1. Studi Kepustakaan

Adalah teknik pengumpulan data yang penulis gunakan, metode yang dimaksud adalah mengumpulkan semua teori dari sumber-sumber kepustakaan. sumber berupa jurnal, informasi situs resmi dan buku-buku yang relevan.

2. Observasi Adalah teknik pengumpulan data, dimana peneliti mengumpulkan semua data melalui pengamatan terhadap subjek penelitian. Pengamatan dilakukan mrlalui laporan keuangan PT. MNC MEDIA secara berkala.

\section{Teknik Pengumpulan Data}

Teknik pengumpulan data dalam penelitian ini adalah dengan teknik dfokumentasi, yaitu dengan cara mengumpulkan data-data yang telah ada dari arsip bursa efek indonesia. Untuk mendapatkan data sekunder, digunakan 
teknik pengumpulan data melalui studi kepusyakaan, yaitu sebagai berikut:

1. Studi Literatur

Dalam Studi Ini, Penulis

Mengumpulkan Semua Data Data

Mengenai Current rasio, Quick rasio, Net profit margin, Earning per share Dan Return Saham.Data Di Dapat Melalui Laporan Keuangan Perusahaan Yang Terdaftar Di Bursa Efek Indonesia.

2. Studi Dokumentasi

Dalam studi ini peneliti melakukan pengumpulan data dari situs-situs yang berhubungan dengan objek penelitian yaitu pojok bursa, google finance, www.mnc.co.id, dan dari situs resmi BEI www.idx.co.id.

\section{Jenis Dan Sumber Data}

\section{Jenis data}

Data yang dipakai adalah data kuantitatif, yaitu data yang berbentuk angka-angka, menunjukan terhadap besaran nilai variabel-variabel yang diwakilinya. Data tersebut bersifat time series, yaitu data berkembang dari waktu ke waktu, sehingga bersifat dinamis karna adanya perubahan waktu.

2. Sumber data

Data yang dipakai adalah data sekunder, yaitu data yang diperoleh dari situs resmi bei, selain itu juga berasal dari www.mnc.co.id. Data tersebut ditunjang oleh data primer yang bersumber dari bukubuku sebagai sumber relevan.

\section{Populasi dan Sample}

Populasi adalah keseluruhan data yang kita dapatkan melalui beragam cara dan teknik pengambilan data, dalam penelitian ini penulis mengambil data PT. MNC MEDIA sekaligus data tersebut adalah sampel untuk penelitian ini, dikarnakan perusahaan bersangkutan belum genap 10 tahun tercatat di BEI ketika penelitian ini dilakukan.

\section{Uji Normalitas}

Uji normalitas data dimaksud untuk mengetahui data yang digunakan dalam penelitian ini bersifat normal atau tidak. Data distribusi dikatakan normal apabila angka signifikannya lebih besar dari 0.05 , selain itu untuk menguji normalitas juga dilakukan dengan melihat laporan kolmogorof-smornov, menurut Idris Fahmi (2011:85) " data dikatakan berdistribusi normal apabila angka signifikan lebih besar dari 0,05 selain itu pengujian juga dilakukan dengan memperhatikan penyebaran titik pada sumbu diagonal dari grafik dasar pengambilan keputusan.

1. Jika data menyebar sepanjang garis diagonal berarti data memenuhi asumsi normalitas

2. Jika data menyebar jauh dari garis diagonal berarti data tidak memenuhi asumsi normalitas

\section{Uji Autokorelasi}

Uji ini dilakukan untuk menguji apakah dalam regresi linearada korelasi antara anggota-anggota dari serangkaian pengamatan yang tersusun berdasarkan waktu. Model regresi yang baik tidak terjadi autokorelasi. Dengan uji Durbin Watson (D-W) menurut Idris (2011:86) “ bila Durbin Watson di bawah -2 berarti korelasi bersifat positif. Bila antara -2 hingga 2 berarti tidak ada autokorelasi. Bila lebih dari 2 berarti negatif.

\section{Uji Multikolinieritas}

Menurut idris (2011:87) “ multikolinearitas adalah sebuah metode yang dipakai dengan cara melihat hubungan antara variabel predictor satu dengan variabel predictor lainnya “. Adalah hubungan antara variabel prediktor dan independen terhadap variabel prediktor lain. Hal ini menyebabkan varians atau standard error koefision regresi tidak akansignifikant berbeda dengan nol. Ketentuannya adalah nilai VIF $>10$ dapat dikatakan terjadi multikolinieritas, selain itu pengujian juga dapat dilakukan dengan melakukan pengamatan nilai Tolerance. Nilai tolerance haruslah berada di atas 0.1 . 


\section{Uji Heterokedastisitas}

Bertujuan untuk mengamati grafik scatterplot antara prediksi variael dependen dengan residualnya. Menurut Agussakim (2014:112)"jika pada grafik scatterplot ada pola tertentu, seperti titik-titik yang membentuk pola tertentu yang teratur maka terjadi heteroskedistisitas."

Jadi secara umum heterokedastisitas adalah sebuah metode pengamatan data melalui kurva scatterplot dimana data dikatakan bebas heterokedastisitas apabila semua variabel menyebar tanpa membentuk pola tertentu.

\section{Analisis Regresi Linear Berganda}

Analisis linear berganda berguna untuk mengetahui pengaruh dengan menentukan nilai Y ( Variabel Terikat) Dan X (Sebagai Variabel Bebas), Dengan Menggunakan Rumus Statistik (2014:91) $\mathrm{b}_{4} \mathrm{x}_{4}$

RUMUS $\mathrm{Y}=\mathrm{a}+\mathrm{b}_{1} \mathrm{x}_{1}+\mathrm{b}_{2} \mathrm{x}_{2}+\mathrm{b}_{3} \mathrm{x}_{3}+$

\section{Uji Koefisien Determinasi}

Uji koefision determinasi digunakan untuk mengetahui seberapa besar pengaruh yang diberikan oleh variabel bebas terhadap variabel terikatnya. Data ditunjukkan dengan nilai persentase, $r^{2}$ sama dengan satu, berarti garis regresi yang dicocokan menjelaskan $100 \%$ variasi dalam $\mathrm{Y}$, sebaliknya kalau r2 sama dengan nol, berarti tidak menjelaskan sedikitpun pengaruh yang terjadi antara variabel bebas dengan variabel terikatnya.

\section{Uji Statistik t}

Uji ini dilakukan untuk memperoleh jawaban atas hipotesis yang pertama. N-2Uji ini dilakukan dengan cara

Jika nilai dari t hitung lebih besar dari nilai $\mathrm{t}$ tabel, maka hipotesis nol ditolak, dengan demikian Ha diterima . selain itu Uji t juga digunakan untuk menguji apakah koefisien regresi signifikan berdasarkan probabilitas. Apabila regresi lebih kecil dari 0.05 maka regresi signifikan.

$$
\begin{array}{r}
\text { Rumus } \mathrm{t}=\frac{\mathrm{r} \sqrt{n}-2}{\left(1-\mathrm{R}^{2} \sqrt{1-r 2) /(n-k-1}\right)}
\end{array}
$$

Tingkat signifikansi yang telah ditetapkan adalah $5 \%$, dengan derajat bebas n-k-1, untuk menentukan nilai $t$ tabel sebagai daerah batas penerimaan ho dan ha. Tingkat signifikansi sebesar $5 \%$ dirasa cukup karna sudah umum digunakan pada setiap penelitian ilmiah.

Ho diterima dan Ha ditolak apabila nilai t hitung $<$ nilai $\mathrm{t}$ tabel

Ho ditolak dan Ha diterima apabila nilai t hitung $>$ nilai $t$ tabel

\section{Uji statistik F}

Uji ini digunakan untuk memperoleh jawaban apakah semua variabel bebas berpengaruh atau tidak terhadap variabel terikatnya. Uji $\mathrm{F}$ dilakukan dengan cara membandingkan nilai dari $\mathrm{F}$ hitung dengan nilai dari $\mathrm{F}$ tabel. Nilai $\mathrm{F}$ tabel diperoleh dari tabel distribusi pada tabel $\mathrm{F}$ pada alfa $=$ $5 \%$. Jika nilai $\mathrm{F}$ hitung lebih besar dari nilai $F$ tabel maka Ho ditolak. Dengan demikian hipotesis alternatif diterima.

$$
\begin{aligned}
& \text { Rumus F hitung } \\
& \mathrm{Fh}=\frac{\mathrm{R}^{2} / \mathrm{K}}{\left(1-\mathrm{R}^{2}\right) /(\mathrm{N}-\mathrm{K}-1)}
\end{aligned}
$$

Tingkat signifikansi yang sudah ditetapkan adalah $5 \%$. Dengan derajat bebas n-k-1, untuk menentukan nilai $t$ tabel sebagai daerah batas penerimaan Ho dan $\mathrm{Ha}$ . tingkat signifikansi sebesar $5 \%$ dianggap tepat karna sering dipakai sebagai standar umum.

Ho diterima dan Ha ditolak apabila nilai $\mathrm{F}$ hitung $<$ nilai $\mathrm{F}$ tabel

Ho ditolak dan Ha diterima apabila nilai $\mathrm{F}$ hitung $>$ nilai $\mathrm{F}$ tabel

\section{HASIL DAN PEMBAHASAN}

\section{Uji Normalitas}

Langkah pertama pada uji asumsi klasik adalah memastikan data yang kita olah berdistribusi normal, data dinyatakan normal apabila nilai signifikansinya di atas 0.05 atau $5 \%$ 
Tabel 1 Hasil Uji Normalitas

\begin{tabular}{|c|c|c|c|c|c|}
\hline & RTRN & CR & QR & NPM & EPS \\
\hline \multirow{4}{*}{ Pearson } & 1,000 &,- 393 &,- 402 &,- 020 &, 161 \\
\cline { 2 - 6 } Correlation &,- 393 & 1,000 &, 992 &, 242 &, 772 \\
\cline { 2 - 6 } &,- 402 &, 992 & 1,000 &, 210 &, 727 \\
\cline { 2 - 6 } &,- 020 &, 242 &, 210 & 1,000 &, 241 \\
\cline { 2 - 6 } &, 161 &, 772 &, 727 &, 241 & 1,000 \\
\hline \multirow{5}{*}{ Sig. (1-tailed) } &. &, 148 &, 142 &, 479 &, 339 \\
\cline { 2 - 6 } &, 148 &. &, 000 &, 265 &, 007 \\
\cline { 2 - 6 } &, 142 &, 000 &. &, 294 &, 013 \\
\cline { 2 - 6 } &, 479 &, 265 &, 294 &. &, 266 \\
\cline { 2 - 6 } &, 339 &, 007 &, 013 &, 266 &. \\
\hline \multirow{5}{*}{ N } & 9 & 9 & 9 & 9 & 9 \\
\cline { 2 - 6 } & 9 & 9 & 9 & 9 & 9 \\
\cline { 2 - 6 } & 9 & 9 & 9 & 9 & 9 \\
\cline { 2 - 6 } & 9 & 9 & 9 & 9 & 9 \\
\cline { 2 - 6 } & 9 & 9 & 9 & 9 & 9 \\
\hline
\end{tabular}

Sumber: Olahan SPSS 23

Dari hasil olahan SPSS 2.3 terlihat, semua data yang diolah memiliki distribusi data yang normal, dikarenakan semua data lolos syarat.Dimana keseluruhan data memiliki signifikansi di atas 5\%.

Dimana untuk nilai signifikansi masing masing variable sebesar,current ratio 0.148 , quick ratio 0.142, net profit margin 0.479, dan earning per share 0.339 .

\section{Uji Autokorelasi}

Tabel 2 Hasil Uji Autokorelasi

\begin{tabular}{|c|c|}
\hline Model & Durbin-Watson \\
\hline 1 & 1,458 \\
\hline
\end{tabular}

Sumber : Olahan SPSS 23

Pada hasil olahan SPSS 23 diperoleh nilai angka Durbin Watson berada pada nilai 1.458 artinya data pada penelitian ini bebas autokorelasi karna data yang diteliti memiliki nilai DW di antara -2 hingga 2.

\section{Uji Multikolinearitas}

Tabel 3 Hasil Uji Multikolineatitas

\begin{tabular}{|c|c|c|c|}
\hline \multicolumn{2}{|c}{ Model } & \multicolumn{2}{|c|}{ Collinearity Statistics } \\
\cline { 3 - 4 } & Tolerance & VIF \\
\hline \multirow{1}{*}{1} & (Constant) & & \\
\cline { 2 - 4 } & CR &, 011 & 9,291 \\
\cline { 2 - 4 } & QR &, 012 & 6,387 \\
\cline { 2 - 4 } & NPM &, 883 & 1,133 \\
\cline { 2 - 4 } & EPS &, 310 & 3,222 \\
\hline
\end{tabular}

Sumber: Olahan SPSS 23

Dari hasil olahan SPSS 23, terlihat nilai tolerance masing masing variabel berada pada nilai di atas 0.1 , dan juga nilai masing masing tolerance sebesar current rasio 0.101 , quick rasio 0.212 , net profit margin 0.883 dan earning per share sebesar 0.310 .

Sedangkan untuk nilai VIF setiap variabel juga berada di bawah 10, dimana nilai VIF untuk masing masing variabel adalah sebagai berikut. Nilai VIF current rasio 9.291, quick rasio 6.387 , net profit margin 1.133, dan earning per share 3.222 artinya semua data terbebas dari multikolinearitas.

\section{Uji Heterokedastisitas}

\section{Gambar 1 Hasil Uji Heterokedastisitas}

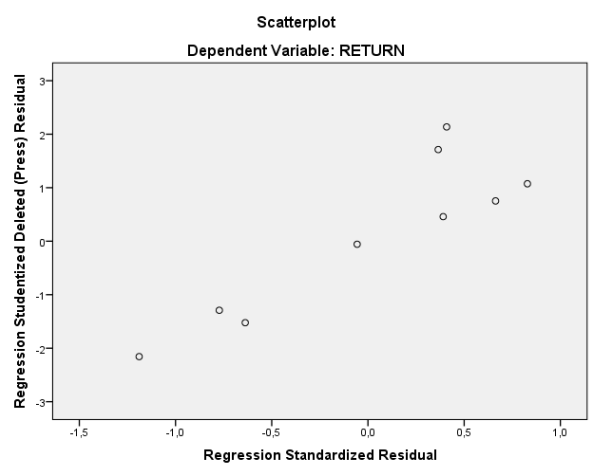

Sumber : Olahan SPSS 23

Dari olahan hasil terlihat semua data menyebar dan tak membentuk pola tertentu.Sehingga dapat disimpulkan bahwa penelitian ini bebas dari heterokedastisitas dan penelitian ini dapat dilanjutkan ke tahap selanjutnya. 


\section{Uji Regresi Linier Berganda}

Tabel 4 Hasil Regresi Berganda

\begin{tabular}{|c|c|c|c|}
\hline \multirow{2}{*}{ Model } & \multicolumn{2}{|c|}{$\begin{array}{c}\text { Unstandardized } \\
\text { Coefficients }\end{array}$} \\
\cline { 3 - 4 } & B & Std. Error \\
\hline \multirow{4}{*}{1} & (Constant) & 152,936 & 89,512 \\
\cline { 2 - 4 } & CR & $-2,022$ & 1,134 \\
\cline { 2 - 4 } & QR & 1,770 & 1,406 \\
\cline { 2 - 4 } & NPM & 1,134 & 3,220 \\
\cline { 2 - 4 } & EPS & 14,870 & 4,498 \\
\hline
\end{tabular}

Sumber : Olahan SPSS 23

Dari table di atas jika dibuat persamaan regresinya adalah sebagai berikut:

Return Saham $=152.932+-2.022 \mathrm{X}_{1}+$ $1.770 \mathrm{X}_{2}+1.334 \mathrm{X}_{3}+14.870 \mathrm{X}_{4}+\mathrm{e}$

1. Angka konstanta a sebesar 152.932 menunjukan perubahan terhadap variabel return jika current rasio, quick rasio, net profit margin dan earning per share konstan.

2. Angka koefisien $b_{1}$ menunjukan perubahan current rasio sebesar -2.022 pada return saham jika variabel current rasio turun satu satuan, dengan anggapan variabel quick rasio, net profit margin dan earning per share konstan.

3. Angka koefisien $\mathrm{b}_{2}$ menunjukan perubahan quick rasio sebesar 1,770 pada return saham jika variabel quick rasio naik satu satuan, dengan anggapan current rasio, net profit margin dan earning per share konstan.

4. Angka koefisien $b_{3}$ menunjukan perubahan net profit margin sebesar 1.334 pada return saham jika variabel net profit margin naik satu satuan, dengan anggapan current rasio, quick rasio dan earning per share konstan.

5. Angka koefisien $b_{4}$ menunjukkan perubahan earning per share sebesar 14.870 pada return saham jika variabel earning per share naik satu satuan, dengan anggapan semua variabel konstan.

Dari model persamaan regresi diatas, terlihat bahwa dari keseluruhan variabel, hanya variabel $\mathrm{CR}$ yang memiliki hubungan negatif dengan variabel dependennya, variabel lainnya yaitu QR, NPM dan EPS memiliki hubungan positif.

\section{Uji Koefisien Determinasi}

Tabel 5 Hasil Uji Koefisien Determinasi

\begin{tabular}{|c|c|}
\hline Model & Adjusted R Square \\
\hline 1 &, 551 \\
\hline
\end{tabular}

Sumber : Olahan SPSS 23

Uji determinasi menunjukan nilai Adjusted $R$ square sebesar 0,551 hal ini menunjukan bahwa secara bersama sama variabel bebas berpengaruh sebesar $55.1 \%$ terhadap return saham, selebihnya dipengaruhi variabel lain yang tidak diteliti.

\section{Uji Statistik t}

Tabel 6 Hasil Uji Statistik t

\begin{tabular}{|c|c|c|c|}
\hline \multicolumn{2}{|c|}{ Model } & T & Sig. \\
\hline \multirow{4}{*}{1} & (Constant) & 1,709 &, 163 \\
\cline { 2 - 4 } & CR & $-1,783$ &, 149 \\
\cline { 2 - 4 } & QR & 1,259 &, 277 \\
\cline { 2 - 4 } & NPM &, 352 &, 743 \\
\cline { 2 - 4 } & EPS & 3,306 &, 030 \\
\hline
\end{tabular}

Sumber : Olahan SPSS 23

Selanjutnya menentukan derajat bebasnya, diketahui df adalah 4 dengan signifikansi sebesar 5\% maka diperoleh hasil untuk t tabel 2.776.

1. Pengaruh Current Ratio Terhadap Return Saham

Terlihat pada kolom nilai, variabel $\mathrm{X}_{1}$ memiliki signifikansi sebesar 0.149 , artinya lebih besar dari nilai probabilitasnya $5 \%$, maka ha ditolak dan ho diterima. Variabel $\mathrm{X}_{1}$ mempunya $\mathrm{t}$ hitung -1.783 dengan nilai $\mathrm{t}$ tabel 2.776, dengan begitu dapat diketahui nilai t hitung lebih kecil dari nilai t tabel sehingga disimpulkan bahwa variabel current rasio tidak memiliki pengaruh signifikan terhadap $\mathrm{Y}$. nilai negatif menunjukan variabel $X_{1}$ tidak searah dengan variabel terikatnya.

2. Pengaruh quick ratio terhadap return saham 
Terlihat pada kolom nilai signifikansi diketahui variabel $\mathrm{X}_{2}$ memiliki tingkat signifikansi sebesar 0,277 . Artinya lebih besar dari nilai probabilitasnya 5\%, maka ha ditolak dan ho diterima . variabel $\mathrm{X}_{2}$ mempunyai thitung sebesar 1.259 dengan $\mathrm{t}$ tabel sebesar 2.776, jadi nilai t hitung lebih kecil dari nilai $t$ tabel dan dapat disimpulkan bahwa variabel $\mathrm{X}_{2}$ berpengaruh tidak signifikan terhadap $\mathrm{Y}$, nilai positif menunjukan hubungan yang searah antara $\mathrm{X}_{2}$ dan $\mathrm{Y}$.

3. Pengaruh net profit margin terhadap return saham

Terlihat dari tabel kolom signifikansi, diketahui variabel $\mathrm{X}_{3}$ memiliki tingkat signifikansi sebesar 0,743 . Artinya lebih besar dari nilai probabilitasnya $5 \%$, maka ha ditolak dan ho diterima. variabel $\mathrm{X}_{3}$ mempunyai $t$ hitung sebesar 0,352 dengan $t$ tabel sebesar 2.776, jadi t hitung lebih kecil dari $t$ tabel sehingga dapat disimpulkan bahwa variabel $\mathrm{X}_{3}$ berpengaruh tidak signifikan terhadap $\mathrm{Y}$, nilai positif menunjukan hubungan yang searah antara $\mathrm{X}_{3}$ dan $\mathrm{Y}$.

4. Pengaruh earning per share terhadap return saham

Terlihat dari tabel kolom signifikansi, diketahui variabel $\mathrm{X}_{4}$ memiliki tingkat signifikansi sebesar 0,030 . Artinya lebih kecil dari nilai probabilitasnya 5\%, maka $\mathrm{Ha}$ diterima dan Ho ditolak . variabel $\mathrm{X}_{4}$ mempunyai t hitung sebesar 3.306 , dengan t tabel sebesar 2.776, jadi t hitung lebih besar dari $t$ tabel sehingga dapat disimpulkan bahwa variabel $\mathrm{X}_{4}$ berpengaruh signifikan terhadap $\mathrm{Y}$, nilai positif menunjukan hubungan yang searah antara $\mathrm{X}_{4}$ dan $\mathrm{Y}$.

\section{Uji Statistik F}

Table 7 Hasil Uji Statistik F

\begin{tabular}{|c|c|c|c|}
\hline \multicolumn{2}{|c|}{ Model } & $\mathrm{F}$ & Sig. \\
\hline \multirow{3}{*}{1} & Regression & 3,481 &, $002^{\mathrm{b}}$ \\
\hline & Residual & & \\
\hline & Total & & \\
\hline
\end{tabular}

Sumber: Olahan SPSS 23

Berdasarkan hasil olahan SPSS 2.3 diperoleh tingkat signifikansi sebesar 0.002 atau dengan kata lain berada di bawah 5\%. Untuk mencari nilai $\mathrm{F}$ table maka harus ditentukan dulu Derajat bebas, diketahui pada derajat bebas $\mathrm{df}_{1}$ adalah 4 ( jumlah variabel bebas penelitian), sedangkan $\mathrm{df}_{2}$ adalah 4 maka hasil dari $\mathrm{F}$ table adalah sebesar 6.39 ( tabel $\mathrm{F}$ dilampiran), jika membandingkan dengan nilai $\mathrm{F}$ hitung sebesar 3.481 maka disimpulkan bahwa nilai $\mathrm{F}$ tabel lebih besar dari nilai $\mathrm{F}$ hitung. Dengan demikian dapat disimpulkan bahwa penelitian ini signifikan, artinya secara bersama sama variabel current ratio, quick ratio, net profit margin serta earning per share berpengaruh secara tidak signifikan terhadap Return Saham.

\section{Pengaruh Current RasioTerhadap Return Saham}

Current rasio adalah salah satu rasio likuiditas, dimana rasio ini mengukur bagaimana kemampuan perusahaan dalam memenuhi kewajiban jangka pendeknya. Rasio ini akan semakin baik apabila nilai rasionya semakin tinggi.Pada penelitian ini diketahui bahwa variabel current rasio berpengaruh tidak signifikan terhadap variabel return, diketahui dari perbandingan $t$ hitung dengan $t$ tabelnya, dimana nilai $t$ hitung lebih kecil dari t tabel, nilai t hitung sebesar -1.783 lebih kecil dari $t$ tabel sebesar 2.776, angka current rasio menunjukkan nilai negatif yang artinya terjadi hubungan tak sejalan antara variabel current rasio dengan variabel terikatnya. Apabila current rasio naik satu-satuan akan menyebabkan return saham turun dengan nilai yang sama.

Hasil penelitian ini sendiri sejalan dengan penelitian terdahulu milik Ajeng ika Ariyanti ( 2016), Rio Febriono ( 2016 ), Muhammadinah ( 2015 ), Nardi ( 2012) dengan variabel terikat yang sama namun variabel bebas yang berbeda.

\section{Pengaruh Quick RasioTerhadap ReturnSaham}

Quick rasio adalah salah satu rasio likuiditas, rasio ini bertujuan mengukur kemampuan asset lancer selain persediaan untuk menanggung kewajiban jangka 
pendek perusahaan tersebut. Semakin tinggi nilai dari quick rasio, maka akan semakin baik keuangan perusahaan tersebut. Pada penelitian ini, diketahui bahwa variabel quick rasio berpengaruh tidak signifikan, terlihat dari nilai $\mathrm{t}$ hitung lebih kecil dari $\mathrm{t}$ tabel.Berdasarkan olahan SPSS 2.3 diketahui nilai t hitung sebesar 1.259 lebih kecil dari nilai $t$ tabel sebesar 2.776. Hal ini menunjukkan bahwa variabel quick rasio memiliki hubungan positif dengan variabel return saham, positif dalam artian kedua variabel ini sejalan, apabila return naik satu-satuan maka quick rasio juga akan naik dengan nilai yang sama

Penelitian ini sejalan dengan penelitian terdahulu milik Candi Naari Astiti ( 2014 ) dengan variabel bebas yang berbeda namun variabel terikat sama.

\section{Pengaruh Net Profit MarginTerhadap ReturnSaham}

Net profit margin merupakan salah satu rasio profitabilitas, rasio ini bertujuan untuk mengukur tingkat pendapatan bersih perusahaan di kurangi beban kotornya. Semakin tinggi nilai net profit margin maka akan semakin baik kemampuan perusahaan tersebut.Pada penelitian ini diketahui net profit margin berpengaruh tidak signifikan terhadap return saham, terlihat dari nilai $t$ hitung yang lebih kecil dari $\mathrm{t}$ tabel, $\mathrm{t}$ hitung sebesar 0.352 sedangkan $t$ tabel sebesar 2.776, nilai ini menunjukan hubungan yang positif antara net profit margin dengan return saham. Dimana apabila return naik satu satuan maka net profit margin juga akan naik dengan jumlah kenaikan yang sama.

Penelitian ini mendukung hasil penelitian terdahulu milik Suwitho (2015), Sity Yuliana (2016 ), Hantono ( 2013 ) dengan variabel terikat yang sama nvariabel bebas berbeda.

\section{Pengaruh Earning per ShareTerhadap Return Saham}

Earning per share adalah salah satu rasio profitabilitas, dimana rasio ini mengukur pendapatan yang diperoleh dari penjualan saham per lembarnya, atau sering disebut rasio buku.Pada penelitian ini diketahui earning per share berpengaruh signifikan, terlihat dari nilai $\mathrm{t}$ hitungnya yang lebih besar dari t tabelnya. Dimana nilai $t$ hitung sebesar 3.306 sedangkan $t$ tabel sebesar 2.776, angka ini menunjukan terjadinya hubungan yang positif antara variabel earning per share dengan return saham, apabila return naik satu satuan maka earning per share juga akan naik dengan jumlah yang sama.

Sekaligus penelitian ini mendukung hasil penelitian terdahulu milik Rio Febrioni ( 2016 ), Risdiyanto ( 2016 ), Candi Naari Astiti ( 2016 ), Gede Gilang Gunadi ( 2015 ), Latifah Ratnasari. Dengan variabel bebas berbeda namun variabel terikat yang sama.

Pengaruh Current Rasio, Quick Rasio, Net Profit Margin Dan Earning Per Share Terhadap Return Saham

Semua rasio berpengaruh tidak signifikan terhadap variabel terikatnya, hal ini terlihat dari nilai $\mathrm{F}$ hitung lebih kecil dari $\mathrm{F}$ tabel, dimana diketahui bahwa $\mathrm{F}$ hitung sebesar 3.481 sedangkan $F$ tabel sebesar 6.39, angka ini menunjukan hubungan yang positif antara return saham dengan semua variabel bebasnya, artinya apabila return mengalami kenaikan satusatuan akan menyebabkan perubahan yang sama terhadap semua variabel bebasnya.

Hasil penelitian ini sejalan dengan penelitian terdahulu milik riyanti Syahputri ( 2016 ), Cokorda Indah ( 2012 ) memiliki kesamaan pada variabel terikat namun berbeda pada variabel bebasnya.

\section{KESIMPULAN DAN SARAN}

\section{Kesimpulan}

Berdasarkan hasil pembahasan pada penelitian maka kesimpulan yang dapat diambil adalah:

1. Current Rasiotidak berpengaruh secara signifikan terhadap Return Saham Pada PT. MNC MEDIA yang terdaftar di Bursa Efek Indonesia, hal ini dibuktikan dengan nilai $t$ hitung 
sebesar -1,783 lebih kecil dari t tabel sebesar 2,776.

2. Quick Rasiotidak berpengaruh secara signifikan terhadap Return Saham Pada PT. MNC MEDIA yang terdaftar di Bursa Efek Indonesia hal ini dibuktikan dengan nilai $t$ hitung sebesar 1,259 lebih kecil dari t tabel sebesar 2,776.

3. Net Profit Margintidak berpengaruh secara signifikan terhadap Return Saham pada PT. MNC MEDIA yang terdaftar di Bursa Efek Indonesia dibuktikan dengan nilai $t$ hitung sebesar 0.357 lebih kecil dari t tabel sebesar 2,776.

4. Earning Per Shareperpengaruh secara signifikan terhadap Return Saham pada PT. MNC MEDIA di Bursa Efek Indonesia dibuktikan dari nilai $\mathrm{t}$ hitung sebesar 3,306 lebih besar dari t tabel sebesar 2.776

5. Current Rasio, Quick Rasio, Net Profit Margin Dan Earning Per Sharesecara simultan tidak berpengaruh signifikan terhadap Return Saham pada PT. MNC MEDIA yang terdaftar di Bursa Efek Indonesia, dibuktikan dengan nilai $\mathrm{F}$ tabel sebesar 6,39 lebih besar dari $\mathrm{F}$ hitung sebesar 3.481 .

\section{Saran}

1. Bagi perusahaan sebaiknya mempertimbangkan variabel earning per share, yang berpengaruh signifikan sebagai dasar perbaikan kinerja perusahaan hal ini dikarenakan variabel earning per share sangat diperhatikan investor sebelum memutuskan membeli atau menjual saham.

2. Bagi investor sebaiknya mempertimbangkan variabel earning per share sebagai pertimbangan mencari return maksimal.

3. Untuk peneliti yang ingin melakukan penelitian dengan topik yang sama, sebaiknya mengganti dengan variabel yang berbeda sebagai pengembangan wawasan dan teori, atau mengganti perusahaan lain sebagai penambah pengetahuan.

\section{DAFTAR PUSTAKA}

Budiyanto, 2017. Pengaruh Der, Per Dan Roe Terhadap Return Saham Pada Perusahaan Telekomunikasi. Jurnal Ilmu Dan Riset Manajemen Volume 6 Nomer 6

Aisyah, Ayunurhayani. 2016. Pengaruh Roe, Eps, Firm Size Dan Operating Cash Flow Terhadap Return Saham. EJurnal Manajemen Unud, Volume 5.Nomer 11

Arianti, Ajengika, 2016.Pengaruh Cr, Tato, Npm Dan Roa Terhadap Return Saham. Jurnal Ilmu Dan Riset Manajemen.Volume 5, Nomer 4.

Febriono, Rio. 2016. PengaruhRoa, Roe, Eps Dan Cr Terhadap Return Saham Pada Perusahaan Yang Terdaftar Di LQ45 Pada Bursa Efek Indonesia Tahun 2011-2015. E-Proceding Of Manajemen.Volume 3, Nomer 3.

Indah, Cokorda. 2016. Pengaruh Der, Per Dan eva terhadap Return Saham Pada Perusahaan Makanan Dan Minuman. E-JurnalManajemenUnud, Vol 5

Nomer 3

Retnasari, Latifah. 2016.Pengaruh npm, Roe, Dan Eps Terhadap Return Saham Pada Perusahaan Farmasi Di Bei. Jurnal Ilmu Dan Riset Manajemen, Volume 5, Nomer 12.

Risdiyanto. 2016. Pengaruh Roa, Eps Dan Der Terhadap Return Saham Pada Perusahaan Farmasi. Jurnal Ilmu Dan Riset Manajemen, Vol 5 Nomer 7.

Sity, Yuliana.2016. Pengaruh Profitabilitas Dan Current Rasio Pada Perusahaan Farmasi.JurnalIlmuDanRiset Manajemen.Vol 5. No 6.

Suwitho, 2016.Pengaruhroa, Firm Size Dan Npm Terhadap Return Saham Pada Perusahaan Semen.Jurnal ilmu dan riset manajemen, Volume 5, Nomer 1.

Gunadi, Gedegilang, Dkk.2015. Pengaruh Roa, Der Dan Eps Terhadap Return Saham Pada Perusahaan Food And Beverage Di Bei. E-Jurnal Manajemen Unud Vol 4 No 6.

Muhammadinah, Dkk. 2015.Pengaruh Current Ratio, Debt To Equity, Tato Dan Roa Terhadap DevidenIEconomic Journal, Vol 1. No 1. 
Syahputri, Rianti, 2015. Pengaruh Roa, Npm Dan Eps Terhadap Return Saham Pada Emiten Jii Tahun 2010-2013. Jesit Volume 2, Nomer 4.

Astiti, Candina Ari Dkk. 2014. Pengaruh Laporan Keuangan Terhadap Return Saham Studi Kasus Pada Prusahaan Otomotif Dan Komponen Di Bursa Efek Indonesia. Jurnal Ilmu DanRiset Manajemen,Volume3, Nomer 2

Hantono. 2013. Pengaruh Cr, Der Terhadap ProfitabilitasPadaPerusahaan Manufaktur Sektor Logam Di Bursa Efek Indonesia. Jurnal Wira Ekonomi Mikro Skil, Vol 5, No 1

Syahrial, Darmawan. 2013, Analisis Laporan Keuangan, Mitra Wacana Media:Jakarta

Fahmi, Idris. 2012. Pengantar Pasar Modal, Alfabeta:Bandung

Kasmir. 2012. Analisis Laporan Keuangan, Edisirevisi, Penerbit Raja Grafindo Persada:Jakarta.

Nardi. 2012. Pengaruh Der, Cr, Npm Dan Roi Terhadap Harga Saham. I-Jurnal Economic.Volume 3, No 1.

Idris . 2011. Metode Penelitian Kuantitatif, Kualitatif. Rajawali Persada:Jakarta

Kasmir. 2011 . Analisis Laporan Keuangan. Raja Grafindo Persada:Jakarta

Sugiyono. 2011. Metode Penelitian Pendidikan. Alfabeta:Bandung

Harahap, Sofyan S. 2010.Analisis Kritis Atas Laporan Keuangan, Rajawali Persada:Jakarta

Jumingan. 2010, Analisis Laporan Keuangan, Cetakan Keempat, Penerbit Bumi Aksara: Surakarta.

Mardiyanto. 2010. Analisis Laporan Keuangan,Balai Pustaka:Jakarta.

Martono, Agus Harjito. 2010. Manajemen Keuangan. EdisiPertama. Ekonisia: Yogyakarta

Munawir. 2010. Analisis laporan keuangan, Liberty:Jogyakarta

Riyanto, Bambang.2010, Dasar - Dasar PembelajaranPerusahahaan.Edisi Keempat, Cetakan Kesepuluh, Penerbit Bpfe:Yogyakarta

Tandelilin, Eduardus. 2010. Portofolio Dan Investasi teori Dan Aplikasi,Edisi Pertama, Kanisius Ikapi:Yogyakarta. 